\title{
$\left[\mathrm{Co}(\mathrm{phen})_{2}\left(\mathrm{CO}_{3}\right)\right] \cdot\left(\mathrm{HCO}_{3}\right) \cdot 4 \mathrm{H}_{2} \mathrm{O}$ 의 수열합성과 결정구조
} (phen=1,10-phenanthroline)

\author{
구본권* - 김정숙 - 임우택 ${ }^{\dagger}$ \\ 대구기톨릭대학교 화학과 \\ 안동대학교 응용화학과
}

(2007.816접수)

\section{Hydrothermal Synthesis and Crystal Structure of $\left[\mathrm{Co}(\text { phen })_{2}\left(\mathrm{CO}_{3}\right)\right] \cdot\left(\mathrm{HCO}_{3}\right) \cdot 4 \mathrm{H}_{2} \mathrm{O}$ (phen=1,10-phenanthroline)}

Bon Kweon Koo*, Jungsook Kim and Woo Taik Lim*

Department of Chemishy; Catholic University of Daegu, Gyeongsan, Gveongbuk 712-702. Korea

${ }^{\dagger}$ Department of Applied Chemistry, Andong National University; Andong. Gyeongbuk 7601-749, Korea

(Received August 16, 2007)

주제어: $\mathrm{Co}(\mathrm{III})$ 착물, 수열합성, 결점구조

Keywords: Co(III) Complex. Hydrothermal Synthesis, Crystal Stucture

The self-assembly of highly organized metalorganic frameworks comprised of metal ions as nodes and bridged ligands as spacers has achieved considerable progress in supramolecular chemistry and material chemistry. ${ }^{1 \cdot 4}$ The increasing interest in this field is not only because of their intriguing variety of architectures and topologies, but also because of their potential applications as functional materials. ${ }^{--9}$ By selecting appropriate metal ions and bridged ligands, coordination polymers with fantastic structures and desirable properties can be obtained. The dicarboxylato ligand and d-block metal ions have been extensively used in much of this work. ${ }^{\text {10 }}$ The coordination polymers bearing dicarboxylato anion ligands have been shown to form a wide range of interesting network topologies, for examples, 1D chains, 2D open layers, and 3D diamondoid networks." In our ongoing investigation on the coordination chemistry of d-block metal(II) complexes containing diamine and/or dicarboxylate anion, the monomeric title conpound 1 was obtained by the reaction of phen and malonic acid with the $\mathrm{CoCO}_{3} \cdot \mathrm{xH}_{2} \mathrm{O}$. The crystal structures of some cobalt(III) complexes with phen and other ligands have been studied, such as $\left[\mathrm{Co}\left(\mathrm{phen}_{2} \mathrm{Cl}_{2}\right]\right.$ $\mathrm{Cl}_{3} 3 \mathrm{H}_{2} \mathrm{O},\left[\mathrm{Co}(\text { phen })_{2} \mathrm{CO}_{3}\right] \cdot \mathrm{X}\left(\mathrm{X}=\mathrm{Cl}, \mathrm{Br}, \mathrm{NO}_{5}\right.$, and $\left.\mathrm{ClO}_{4}\right)^{1 .}$ However, to our knowledge, trivalent cobalt conplex with bicarbonate as counter ion in the formula is not known up to now. Thereby, we report here the preparation and structure of 1 .

\section{EXPERIMENTAL}

Synthesis. All chemicals were commercially purchased and used without further purification. Elemental analyses $(\mathrm{C}, \mathrm{H}, \mathrm{N})$ were perfonmed on a Carlo Erba EA-1106 Elemental Analyzer. IR spectrum was recorded in the range $400-4000 \mathrm{~cm}^{-1}$ on a Mattson Polaris FT-IR Spectrophotometer using $\mathrm{KBr}$ pellets. The initial and final $\mathrm{pH}$ of the 
reaction was measured using Sentron $1001 \mathrm{pH}$ meter.

A mixture of $\mathrm{CoCO}_{3} \mathrm{XH}_{2} \mathrm{O}(0.059 \mathrm{~g}, 0.5 \mathrm{mmol})$, $\mathrm{HO}_{2} \mathrm{CCH}_{2} \mathrm{CO}_{2} \mathrm{H}(0.052 \mathrm{~g}, 0.5 \mathrm{mmol}), 1,10$-phen $(0.180 \mathrm{~g}, 1.0 \mathrm{mmol})$, and water $(9 \mathrm{ml}, 500 \mathrm{mmol})$ in the mole ratio 1:1:2:1000 was placed in a 23 $\mathrm{ml}$ Teflon-lined Parr acid digestion bomb and heated for $2 \mathrm{~d}$ at $150^{\circ} \mathrm{C}$ under autogenous pressure. After the mixture was removed from the oven and allowed to cool under ambient conditions for $3 \mathrm{~d}$, the red needles of 1 suitable for X-ray diffraction were isolated in $20 \%(0.06 \mathrm{~g})$ yield based on cobalt. Initial $\mathrm{pH}, 4$; final $\mathrm{pH}, 5$. Anal. Calcd. for $\mathrm{C}_{\unlhd 6} \mathrm{H}_{₫} \varsigma \mathrm{CoN}_{4} \mathrm{O}_{\mathrm{u}}$ : C, 50.99; H, 4.11; N, 9.15 . Found: C, 50.92; H, 4.15; N, 9.18. IR ( $\mathrm{KBr}$ pellet, $\left.\mathrm{cm}^{-1}\right): 3409(\mathrm{~s}), 1628(\mathrm{~m})$, $1565(\mathrm{~s}), 1517(\mathrm{~m}), 1422(\mathrm{~s}), 1385(\mathrm{~m}), 849(\mathrm{~m}), 724(\mathrm{~m})$, $646(\mathrm{~m})$.

X-ray crystallography. X-ray diffraction data of the single crystal was collected at 293(2) K on an ADSC Quantum 210 detector at Beam-line 4A MXW of Pohang Light Source. The crystal evaluation and data collection were done using $0.77001 \AA$ wavelength radiation with a detector-to-crystal distance of $6.0 \mathrm{~cm}$. Prelininary cell constants and an orientation matrix were determined from 36 sets of frames collected at scan intervals of $5^{\circ}$ with an exposure time of $1 \mathrm{~s}$ per frame. The basic scale file was obtained from program HKL2000. ${ }^{13}$ The reflections were successfully indexed by the automated indexing routine of the DENZO program. A total of 29,499 reflections were harvested by collecting 72 sets of frames with $5^{\circ}$ scans with an exposure time of 1 second per frame. This highly redundant data set was corrected for Lorentz and polarization effects, and a (negligible) correction for crystal decay was also applied. The space group P-1 was determined by the progran XPREP (ver. 6.12, Bruker-AXS). The structure was solved by direct method $^{1+t}$ and refined on $F^{2}$ by full-matrix leastsquares procedures. ${ }^{\text {is }}$ All non-hydrogen atoms were refined using anisotropic themal parameters. Hydrogen atoms were included in the structure factor calculation
Toble 1. Crystal data and stnucture refinement for $\mathbf{1}$

\begin{tabular}{|c|c|}
\hline Empirical formula & $\mathrm{C}_{24} \mathrm{H}_{26} \mathrm{CoN}_{4} \mathrm{O}_{10}$ \\
\hline Formula weight & 612.44 \\
\hline $\mathrm{T}(\mathrm{K})$ & $293(2)$ \\
\hline$\lambda(\AA)$ & 0.77001 \\
\hline Crystal system & Triclinic \\
\hline Space group & P-1 \\
\hline$a(\AA)$ & $7.9750(16)$ \\
\hline$b(\dot{A})$ & $10.415(2)$ \\
\hline$c(A)$ & $16.578(3)$ \\
\hline$\alpha(\%)$ & $106.27(3)$ \\
\hline$\beta(a)$ & $103.41(3)$ \\
\hline$y\left(0^{\circ}\right)$ & $90.23(3)$ \\
\hline$V\left(\AA^{j}\right)$ & $1282.3(4)$ \\
\hline$Z$ & 2 \\
\hline$\mu\left(\mathrm{mmn}^{-1}\right)$ & 0.737 \\
\hline$F(000)$ & 618 \\
\hline$\left.\theta 0^{\circ}\right)$ & 1.43 to 30.40 \\
\hline Limiting indices & $\begin{array}{l}0<=h<=10,-13<=k<=13 \\
-20<=1<=20\end{array}$ \\
\hline Reflections collected/unique & $5516 / 5516[\mathrm{R}(\mathrm{int})=0.0000]$ \\
\hline Absorption correction & None \\
\hline Goodness-of-fit on $F^{2}$ & 1.039 \\
\hline$R_{1}[I \geq 2 \sigma(I)]$ & 0.0524 \\
\hline$w R_{2}[I \geq 2 \sigma(I)]$ & 0.1551 \\
\hline Largest peak and hole $\left(e \AA^{-j}\right)$ & 0.603 and -0.746 \\
\hline
\end{tabular}

at idealized positions by using riding model, but not refined. A summary of the experimental and crystallographic data for compound $\mathbf{1}$ is presented in Table 1.

\section{RESULTS AND DISCLSSION}

The hydrothermal reaction of $\mathrm{CoCO}_{3} \mathrm{xH}_{2} \mathrm{O}$, $\mathrm{HO}_{2} \mathrm{CCH}_{2} \mathrm{CO}_{2} \mathrm{H}, 1,10$-phen, and water in the nole ratio $1: 1: 1: 1000$ at 150 for $2 \mathrm{~d}$ yielded the title compound in $20 \%$ yield as red needles. The nalonic acid present in the initial reaction mixture was not found in the crystalline product. It is not unconmon for necessary reactants in hydrothernal processes to be absent from the product, while their specific role in conplexation remains elusive. ${ }^{16}$ It may be that nalonic acid acts to fom the bicarbonate ion $\left(\mathrm{HCO}_{3}^{-}\right){ }^{17}$ The formal valence of cobalt atom on 


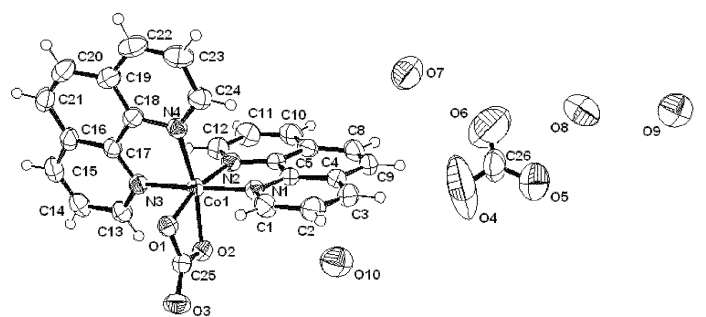

(a)

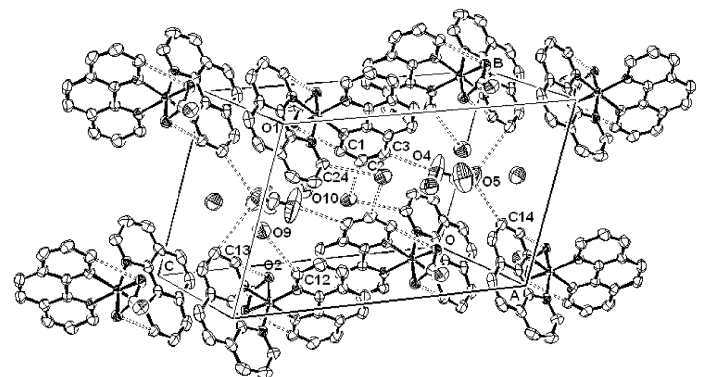

(b)

Fig. 1. (a) ORIt]' tepresentation of the comroplex, [Co(phost) $(\mathrm{CO})]-$ $\mathrm{H}_{2}\left(\mathrm{CO}_{3}-\mathrm{H}_{2} \mathrm{O}\right.$ at $30 \%$ probability and (b) packing digram showing the hydrgen bonds in the unit oell (hydrogen atoms were onitted tor clarity).

the basis of overall charge consideration in the formula is Co(III). The oxidation state is conformed from bond valence calculations. ${ }^{\text {I }}$

As shown in Fig. l(a), the structure of 1 contains a six-coordinated cobalt atom chelated by 1 wo phen ligands and one carbonate anion. The cobalt

Table 2. Selected bond lengths $(\lambda)$ and angles (u) for $\mathbf{I}$

\begin{tabular}{|c|c|c|c|}
\hline $\operatorname{Co}(1)-C(1)$ & $1.887(2)$ & $\operatorname{Co}(1)-O(2)$ & $1.896(2)$ \\
\hline $\mathrm{Co}(1)-N(3)$ & $1.935(2)$ & $\operatorname{Co}(1)-N(1)$ & $1.938(2)$ \\
\hline $\operatorname{Co}(1)-N(4)$ & $1.951(2)$ & $C o(1)-N(2)$ & $1.962(2)$ \\
\hline$C(25)-O(3)$ & $1.223(3)$ & $C(25)-0(1)$ & $1.321(3)$ \\
\hline$C(25)-O(2)$ & $1.323(3)$ & $C(26)-0(4)$ & $1.153(6)$ \\
\hline$C(26)-O(5)$ & $1.193(5)$ & $C(26)-0(6)$ & $1.209(6)$ \\
\hline$O(1)-C O(1)-O(2)$ & $69.63(8)$ & $O(1)-C o(1)-N(3)$ & $90.50(9)$ \\
\hline$O(2)-C o(1)-N(3)$ & $92.13(9)$ & $O(1)-C(1)-N(1)$ & $91.07(9)$ \\
\hline$O(2)-C o(1)-N(1)$ & $89.31(9)$ & $N^{\prime}(3)-C o(1)-N(1)$ & $178.16(8)$ \\
\hline$O(1)-C o(1)-N(4)$ & $96.75(8)$ & $O(2)-\mathrm{C} O(1)-\mathrm{N}(4)$ & $165.86(9)$ \\
\hline$N(3)-C o(1)-N(4)$ & $84.00(9)$ & $N^{\prime}(1)-C \cdot O(1)-N(4)$ & $94.87(9)$ \\
\hline$O(1)-C o(1)-N(2)$ & $167.33(8)$ & $O(2)-\operatorname{Co}(1)-N(2)$ & $98.7+(8)$ \\
\hline$N(3)-C o(1)-N(2)$ & $95.08(9)$ & $N(1)-C o(1)-N(2)$ & $83.57(9)$ \\
\hline$N(4)-C o(1)-N(2)$ & $95.15(9)$ & $O(3)-C(25)-O(1)$ & $124.9(3)$ \\
\hline$O(3)-C(25)-O(2)$ & $125.6(3)$ & $O(1)-C(25)-O(2)$ & $109.5(2)$ \\
\hline$O(4)-C(26)-O(5)$ & $120.7(6)$ & $O(4)-C(26)-O(6)$ & $120.8(5)$ \\
\hline$O(5)-C(26)-O(6)$ & $118.4(5)$ & & \\
\hline
\end{tabular}

center has a distorted octahedral geometry and is surrounded by four nitrogen atons of two phen (N(1)-N(4)) and the two oxygen atoms of carbonato ligand, $O(1)$ and $O(2)$. The bite angles of phen and carbonato chelate rings to the cobalt atom are ca. $83.79(9)^{\mathrm{k}}$ and $69.63(8)^{\prime \prime}$, respectively, which are almost the same with other complexes." The small bite of the $\mathrm{CO}_{3}{ }^{-2}$ ligand produces a significant distortion from a regular octahedron, with other angles also deviating from 90 or $180^{\circ}$ (Table 2). Cobalt-nitrogen bond distances (CO-NI 1.938(2). Co-N2 $1.962(2) \AA)$ are in agreement with $1.936(15) \AA$ found in $\left[\operatorname{Co}\left(\mathrm{NH}_{3}\right)_{6}\right]_{s^{*}}{ }^{10}$ lt is also known that a Co-N bond distance of approximately $1.9 \AA$ is characteristic of $\mathrm{Co}(\mathrm{III})$ and is about $0.18 \overline{\mathrm{A}}$ shorter then the corresponding distanee in Co(II) complexes. ${ }^{20}$ The bond distances of Co-N2 and Co-N 4 which are trons to the carbonato ligand are slightly longer than those of $\mathrm{CO}-\mathrm{NI}$ and $\mathrm{Co}-\mathrm{N} 3$ which are cis to the carbonato ligand. This can be interpreted on the basis of the trans effect to oxygen atoms of carbonato ligand. The $\mathrm{Co}-\mathrm{O}$ bond distances (ca. $1.89 \AA$ ) of carbonato ligand are consistent with bidentate coordination found in the other [Co(phen)$\left.\left(\mathrm{CO}_{3}\right)\right]^{-}$structures. ${ }^{2}$ The $\mathrm{C}-\mathrm{O}$ bond distances of carbonato ligand reveal two longer $\mathrm{C}-\mathrm{O}_{\text {conus. }}$ bonds 
(ca. $1.322(3) \AA$ ) and the shorter $\mathrm{C}-\mathrm{O}_{\text {uncound }}$ bond (1.223(3) $\AA$ ). The two coordinated oxygens have more single bond character than the unbound oxygen. Thus, this result is not at all surprising. However, the shorter bond distances of $\mathrm{C}-\mathrm{O}$ (1.153(6)-1.209(6) $\AA$ ) in the bicarbonate acting as a counter ion are distinguished from those of carbonato ligand. The bond disatance of $\mathrm{C} 26-06$ $(1.209(6) \AA)$ is longer than those of C26-O4 $(1.153(6) \AA)$ and $C 26-05(1.193(5) \AA)$, indicating that the oxygen atom, $\mathrm{O} 6$ is protonated. The rest of the $\mathrm{C}-\mathrm{N}$ and $\mathrm{C}-\mathrm{C}$ bond distances of the phen ligand are all considered normal and agree well with those found in other complexes. ${ }^{\text {liv }}$ The mononuclear structure of $\mathbf{1}$ is further expended through weak hydrogen bonds between carbon atoms of 1,10-phen ring and oxygen atoms of uncoordinated water $\left(\mathrm{C}_{2}-\mathrm{H} 2 \cdots \mathrm{OlO} \mathrm{d}(\mathrm{D} \cdots \mathrm{A})=\right.$ $3.512(4) \AA \angle(D-H \cdots A)=175^{\circ}, \mathrm{Cl} 2-\mathrm{H} 12 \cdots \mathrm{O} 9 \AA$ $\mathrm{d}(\mathrm{D} \cdots \mathrm{A})=3.264(4) \AA \angle(\mathrm{D}-\mathrm{H} \cdots \mathrm{A})=141^{\circ}$, and $\mathrm{C} 24-$ $\mathrm{H} 24 \cdots \mathrm{O} 10(1-\mathrm{x}, 1-\mathrm{y}, 1-\mathrm{z}) \mathrm{d}\left(\mathrm{D}^{\cdots} \mathrm{A}\right)=3.270(4) \AA$ $\left.\angle\left(\mathrm{D}-\mathrm{H}^{+\cdots} \mathrm{A}\right)=134^{\circ}\right)$ or bicarbonate ions $(\mathrm{C} 3-\mathrm{H} 3$ $\cdots \mathrm{O} 4 \mathrm{~d}(\mathrm{D} \cdots \mathrm{A})=3.214(6) \AA \angle\left(\mathrm{D}-\mathrm{H}^{\cdots} \cdot \mathrm{A}\right)=164^{\circ}, \mathrm{C} 14-$ $\left.\left.\mathrm{H} 14^{*} \cdot \mathrm{O} 5 \mathrm{~d}(\mathrm{D}+\mathrm{A})=3.316(6)\right) \AA \angle\left(\mathrm{D}-\mathrm{H}^{+\cdots} \mathrm{A}\right)=137^{\circ}\right)$, respectively. In addition, there is two types of intramolecular hydrogen bonds between carbon atoms of 1,10-phen ring and oxygen atoms of carbonate ion $\left(\mathrm{C} 1-\mathrm{H} 1 \cdots \mathrm{O} 1 \mathrm{~d}\left(\mathrm{D}^{\cdots} \cdot \mathrm{A}\right)=2.928(3) \AA\right.$ $\angle\left(\mathrm{D}-\mathrm{H}^{\cdots} \cdot \mathrm{A}\right)=110^{\circ}$ and $\mathrm{C} 13-\mathrm{H} 13 \cdots \mathrm{O} 2 \mathrm{~d}\left(\mathrm{D}^{\cdots} \cdot \mathrm{A}\right)$ $\left.=3.002(3) \AA \angle\left(\mathrm{D}-\mathrm{H}^{*} \cdot \mathrm{A}\right)=109^{\circ}\right)$. The packing diagran showing hydrogen bonds is shown in Fig. 1(b).

The IR spectrum of the title compound show characteristic band at $1628 \mathrm{~cm}^{-1}$ for the $\mathrm{C}=\mathrm{O}$ stretching vibration. The absence of the carbonyl peak near $1700 \mathrm{~cm}^{.1}$ for the carbonic acid indicates the presence of carbonate and/or bicarbonate ion in the formula. ${ }^{21}$ The strong absorption band at $3409 \mathrm{~cm}^{-1}$ is assigned to the $v(\mathrm{OH})$ of uncoortinated water molecules.

In conclusion, we have synthesized a new title compound $\left[\mathrm{Co}(\text { phen })_{2}\left(\mathrm{CO}_{3}\right)\right] \cdot\left(\mathrm{HCO}_{3}\right) \cdot 4 \mathrm{H}_{2} \mathrm{O}$ from the reaction mixtures of $\mathrm{COCO}_{3} \times \mathrm{xH}_{2} \mathrm{O}, \mathrm{HO}_{2} \mathrm{CCH}_{2} \mathrm{CO}_{2} \mathrm{H}$, 1,10-phen, and water by hydrothermal reaction. It is noteworthy that the complex is the first example of cobalt(III) complex with both carbonate and bicarbonate ion in the crystal structure.

Supplementary materials. Crystallographic data for the structure reported here have been deposited with the Cambridge Crystallograplic Data Centre (Deposition NO. CCDC-647828). The data can be obtained free of charge via www.ccdc.can.ac.uk/ data request/cif.

Acknowledgement. X-ray data was obtained from the Pohang Light Source, Rep. of Korea. We thank the staff at beanline $4 \mathrm{~A} \mathrm{MXW}$ of Pohang Light Source for assistance during data collection.

\section{REFERENCES}

1. Noro, S.; Kitagawa, S.; Kondo, M.; Seki, K. Angent: Chem. Int. Ed. 2000, 39, 2081.

2. Poulton, B.; Zaworotko, M. Chem, Rev: 2001, 101, 1629.

3. Eddacudi, M.; Kim, K.; Rosi, N. L.; Vodak, D. T.; Wacher, ..; O'Keeffe M.; Yaghi, O. M. Science 2002, 295,469

4. Pan, L.; Sander, M. B.; Huang, X. Y.; Li, J.; Snitl, ,M; Bittner, E.; Boclurath, B.; Johnson, J. K. J. Am. Chem. Soc. 2004, 126, 1308

5. Fujita, M.; Kwon, Y. J.; Washizu, S.; Ogura, K. $J$. Am. Chem. Soc. 1994, 116, 1151.

6. Seo, J. S.; Whang, D.; Lee, H.; Jun, S. I.; Ol, J.; Jeon, Y. J.; Kinn, K. Nature 2000, 404,982

7. Benelli, C.; Gatteschi, D. Chem. Rev. 2002, 102, 2369.

8. Janlak, C. J. Chem. Soc., Dalton Trans. 2003, 2781.

9. Dybtsev, D. N.; Chum, H.; Yoon, S. H.; Kim, D.; Kim, K. J. Am. Chem. Soc. 2004, 126, 32.

10. (a) Padmanabbhan, M.; Kumary, S. M.; Huang, X.; Li, I. Inorg Chim Acta 2005, 358, 3537. (b) Ghosh, S. K; Fallah, M. S. E.; Ribas, I.; Bharadwaj, P. K. Inorg. Chim. Acta 2006, 359, 468. (c) Theng, Y. Q; Kong, $Z$. P. Inorg. Chem. Commun 2003, 6, 478. (d) Ye, B. H.; Tong, M. L.; Chen, X. M. Coord. Chem. Rev: 2005, 249,545

11. (a) Low, B. Y.; Yuan, D. Q.; Wu, B. L.; Han, L.; Jiang, F. L.; Hong, M. C. Inorg. Chem. Commm. 2005, 8, 539 . (b) Ohata, N.; Masuda, H.; Yanauchi, O. Angen: Chem. Int. Ed. 2004, 43, 5016. (c) Lou, B. Y.; Wang, R. H.; 
Yuan, D. Q; Wu, B. L.; Jiang, F. L.; Hong, M. C. Itorg. Chem Commun 2005, 8, 971. (d) Mahata, P; Natarajan, S. Eut J. horg. Chent 2005, 2156.

12. (a) Ye, B. H.; Chen, X. M.; Zeng, T. X; Ji, L. N. Pollhedon, 1994, 13, 2185. (b) Niederhoffer, E. C.; Martell, A. E.; Rudolf, P.; Clearfield, A. Inorg. Chem. 1982, 21, 3734. (c) Junk, P. C.; Steed, J. W. Polvhedron, 1999, IS, 3593.

13. Otwinowski, Z.; Minor, W. Methods Enzmmol. 1997, 276, 307.

14. Sheldrick, G .M. Acta Crnst. 1990, A46, 467.

15. Sheldrick, G M. SHELXS97-2 and SHELXI97-2; University of Gottingen: Gottingen, Gemany, 1997.

16. (a) Soghomonian, V.; Chen, Q.; Haushalter, R. C.; Zubieta, J.; O'Connor, C. J. Science 1993, 259, 1596. (b)
Zapf, P. I.; Haushalter, R. C.; Zubieta, J. Chem. Water. $1997,9,2019$.

17. Zheng, Y. Q.; Sun, J.; Lin, J. L. Z. Anong. Allg. Chem. 2000, 626, 613.

18. (a) Brown, I. D.; O'Keefe, M.; Navrotsky, A. (Eds.), Structure and Bondines in Crystals, Acadenic Press, New York, 1981, vol. II, pp. 1-30. (b) Brown, I. D.; Altermatt, D. Acta Crust. 1985, B41, 244. (c) Brown, I. D. Private conmunication.

19. Kine, N. E.; Ibers, J. A. Acta Cryst. 1969, B25, 168.

20. Reinam, C. W; Zocchi, M.; Mighlell, A. D.; Santoro, A. Acta Cryst. 1971, B27, 2211.

21. Haslim, A.; Hosney, A.; Grassian, V. H. $J$. Am. Chem. Soc. 2004, 126, 8068. 